This report was prepured as an stownt of work sponcored by an agency of the Uniled Sintes Governmeal. Neither the Uniled States Sivernesel nor any apency thereor, nor any of tbeir

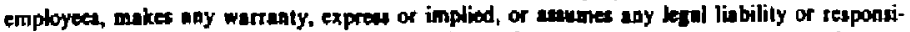
bility for the accuracy, completeseas, or usefulaes of any information, apparatus, product, or process disclowed, or reoresents that iu use would not infringe privalely owned tights. Reference hertin to any specific commercial produet, proces, of service by trade name, trademark. manulacturer, of otherwise does not necesturily constitute or imply its endorsement, recommendation. of favoring by the Unilod States Gowernment or any egency thereat. The views and opinions of authors expreased herein do oot necestarily suate or reflect those of the United States Government or any agency thereor.

\title{
Ion Bernstein Wave Heating
}

\section{on the Compact Ignition Tokamak (CIT)}

\author{
D. W. Ignat and M. Ono \\ Plasma Plysics Laburatory, Princeton Lniversity \\ Princeton, Jew Jersey
}

\begin{abstract}
In the present plan. CIT is to be heated by power in the ion cyrlutrum range of frequencies (IC'RF), and electron cyclotron heating (ECH) may be used if suitable rf sources can be develuped. We comsider the option of ion Bernstein wave heating (IBWH). The key points are that a simple vacuum waveguide launcher can be well-removed from high fluxes if heat and particles and that the develojment of a suitable source is straighterward. A practical print is that an JBWH waveguide launcher, including transition from cuaxial puwer feeds, fits inside the stichd wall surrounding (']T. To confirm IBWH as an uption fur (IT. experinents are needed on a shaped. H.mosle plasma at high puwer. Successful experiments should be folluwed by a tube development prograrn lo allow ClT heating at $200-275.111 \mathrm{z}$.
\end{abstract}




\section{Introduction}

The iun Bernstein wave can deposit energy into thermal ions at several harmunics of the iun cyclutron frequency. At the edge of the plasma, the basmed wave is an electrostatic electron plasma wave which propagates if the clectron plasma frequency is above the wave frequency. Kesonance with a unique component of a D-T plasma can be arranged by chousing the fith harmoric of uritium. yiclding a frequency f.MHz $=25 \mathrm{~B}[\mathrm{Tesla}$. For CIT at full paramoters ( 10 to l/ Tesla), the frequency becomes $250-275 \mathrm{MHz}$, sufticiently high for a wareguide $t$, fit into a port with the long dimension vertical. as required for pruper coupling.

At a reduced ficld of 7 Tesla the fifth harmonic of deuterium ran be used in a non-tritium plasma with a $250 \mathrm{MHz}$ frequency. A $200 \mathrm{MHz}$ frequency heats the fourth harmonic of deuterium without being affected by the tritium resunances.

Fiperimental results on PLT at the 0.65 MW level show good heating, i.e., 6 e $1 \mathrm{k} 14^{4}$ normalized at $\pi$ of $10^{13} \mathrm{~cm}^{3}$. including a reduction in recyeling and a reduction in the level of fluctuations as inferred from mistowave scattering.

Experiments nuw planned un PBX-Ml, Alcator C-Mludification, Doublet III-1). and FT-It should elucidate the ability of IBW to bear at high powes, wn nucircular plasmas, and with waveguides.

\section{Frequency and Waveguide Considerations}

From the puint of view of experimental implementation. IBWH is especially irturesting for mudern tokamaks. The absorption takes place at low to medium harmunics of the jon ryclotron frequency. (Absurptiun at high harmonics is 
called lower hylbrid mode combersion. and is a diflerent discipline of plasma heating.) At liw harmonics coil-style antennas with of sources already built for IC KF exforiments can yield datin on IBWH with minimum expense. At Imediun harmunies the frechuency is high enough that wavegude couplers can lit into the vasum chamber.

lis atowse an appropriate harmonic consider Figure 1, where we plot res(n)ant frequoncy versus magnetic field for the first screral persible hydrogenic species and harmunics. Each line is brodien in two halves, represent ing the high field (10 T) and reduced field ( $7 \mathrm{~T}$ ) oneration of CIT. The Il Tesla possibility fur onjerating (') $T$ is not indicaled wo aroid unneccessary confusjon in this diagram. The high field purtion extends from peak field at $10 \mathrm{~T}$ down to $8.2 \mathrm{~T}$, which represents the tural field at the large major radius edge of the plasma. The poloidal contribution to the tonal field must be taken into account at the edge. as well as the shift of the plasma center ontwards. The desired situation is to chuse a freguency which heats one specie at one harmonic at the center, withust having some other hydrogenic resonance on the low field approach to the certer. For example. look at the fifth harmonic of tritium which resonates with 250 MHz in the center at 10 T: the $250 . \mathrm{HHz}$ Wave misses resonating with the sixth tritium harmonic ( = fourth deuterium = sccond protium) as it enters from the low field side. Therefore, the fifth harmonic of tritium is a suitable rosonance.

On the other hand, the third deuterium harmonic is not sujable because of the presence of the fifth 1 ritium harmonic on the low field side; likewise, the fourth tritium hamonic is not suitable because of the presence of the third donteriam harmunic on the low field side.

Sun consider uperation at reduced field, specitically 7 T. Tritium reso- 
nances are shuwn dashed since the tritium probably would not be present in low field discharges. A pussible chuice is the fourth deuterium harmonic ( = scrond protium) at $200 \mathrm{MHz}$ ur the fifth deuterium barmunic at $250 \mathrm{MHz}$. The resolfafice for the fourth deaterium haremenic is unaffected by tritium which might be in the plastna. Whereas the fift he deuterium harmonic is not practical if tritium is present.

The height of the ports in ('IT is abuut $1 \mathrm{~m}$. A waveguide near cutoff supports a frequency $f=3 \cdot 10^{8}(\mathrm{~m} / \mathrm{sec}) /(2 \cdot 1 \mathrm{~m})=150 \mathrm{MHz}$. Therefore, IBWH can be launched ly waveguide into CIT at full ficld and also at reduced field.

Naveguides with a broad dimension of $1 \mathrm{~m}$ launch the pover at the plasma, lull do not have tu catry the power into the tokamak area. Insteal. cuaxjal transnission of power is desirable from the of somrce to the coupling structure at the plasma.

Figure 2 illustrates, with a scale draxing, a tup vien of a possible installation. Four coaxial lines pass through a shield at the buttom of the drawing, and couple power into four vaveguides. The waveguides taper in the narrus dimension at the entrance to a port flange. but the broad dimension of the wavrguide remains the same. The transmission continues without further transitiun to the plasma. Figure 3 shows a side view of the same installation.

P'mer flow into a port should be similar to the case of ion cyclotron heating, abure $3 \mathrm{MW}$ or mure. This rejuresents about i $\mathrm{kW} / \mathrm{cm}^{2}$. 


\section{Coupling of Waves to Plasma and Plasma to Wave- guide}

The ion Bernstein wave propagates at densities such that the electron plasma frequency is above the excitation frequency. Therefore. a coupler should be placed close to a density of $5 \cdot 10^{8} / \mathrm{cm}^{3}$. Sume coupling calcalations indicate that best results are obtained for a density ten times this. so for the sake of discussion. assume that the waveguide aperture is in plasma of $\mathrm{l} \cdot 10^{10}, \mathrm{~cm}^{3}$ density. At such a density the plasma thermal luading is small. in the range of a kilswatt per square meter.

This simple calculation noeds to be enhanced by results from a coupling corke, including expereded edge density profiles, and analysis of the heat fluxes. Issucs or i : sjectrum. pondermintive effects. ficld strengths. etc. need study also.

Another gond coupling regime urcurs at higher aperture density $-n_{r} \approx$ $10^{12} \mathrm{~cm}^{-3}$ - where direct excitation takes place $\left(f \leq f_{\mathrm{pn}}\right)$. Since the (IT serape-off density profile is not kmown precisely. this additional compling regime "ffers flexibility to the IBWH waveguide coupling. Of cuturse, the thermal loading un the coupler increases as the density rises.

Because of the low density required for compling, BBWH should be compatible with an $\mathrm{H}$-mode plasma.

\section{Previous Experimental Results}

The JBW concept was established at low power on AC'T-I at PPPL.

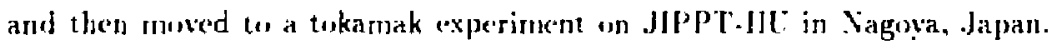
In 1erms of power and heating. the most successful results vere on PlT. 
where iun temperature was raised from $0.5 \mathrm{kel}$ to $2.0 \mathrm{kel}$ with $500 \mathrm{~kW}$ of pwwer. Scaling studies of minurity heating and $3 / 2$ harmonic heating show $6 \mathrm{a} \cdot \mathrm{kW} / 10^{13} \cdot \mathrm{cm}^{-3}$ over the range $0.1 \mathrm{MW}$ to $0.7 \mathrm{MW}$. Other interesting aspect, if the work un PLT are a pussible clecrease in edge turbulence and an increase in particlo confinement associated with IBWH.

Fiperiments at the $180 \mathrm{kH}$ level were carried out on Alcator $\mathrm{C}$. Heating and ismproved particle confinement were found. consistent with the PLT results.

\section{Experiments Needed in the Near Term}

Experiments are planned on PBX-M at $2-4 \mathrm{MW}$ and D-III-D at $2 \mathrm{MW}$ with induction lusp antennas in the period 1989-1990. In these experiments, IBWH in diverted. shaped and $\mathrm{H}$-mode plasmas at high power will be investigated. Naveguide experiments with $450 \mathrm{MHz}$ on FT.U at I MW are planned for 1990 and unward. The FT.C: IBWH experiment offers for the first time a capability lo launch ion Bernstein waves via a CIT-relevant waveguide launcher. In theory. 1he cumpling physics of a waveguide IBWH launcher is simpler than that of a lowp antenna with Faraday shields. In practice, the absence of a luop and Faraday shield from the plasma region can be expected to reduce rperational problems, such as generating impurities, increasing recycling, and breakdown near the antenna. Performance on a waveguide latuncher compared in a loop antenna with Faraday shields is an important future topic for the IBWH experiments. 


\section{Plan for IBWH on CIT}

(:17 can use IBWH without significant mudification to ports and floor spare. Pumer in the range 200-300 $\mathrm{MHz}$ can be provided after a fuur-year lead time to medify the existing Klystrode device of Varian Associates with support Irom (IT for nur-recurring engineering (SIO00K), and install the of smarce.

The best strategy for CIT is tu encourage the planned experiments on PBX-MI and FT-l' while watching progress on the J' 'RF and ECHF physics and technolugy for the mainline CIT prugram. A decision can be made in 1992-3 to transpose some heating power to the IBWH.

\section{Acknowledgements}

This work was funded by the L'nited States Department of Energy, Office of Fusion Energy, under contract DE-AC02-76-C'HO-3073, and vas encouraged by H. P. Furth and J. A. Schmidt. This report is adapted from CIT Document A.1-881018-PPL-04. 
Bitztiography

1. M. Onw. "lon Bernstein Have Heating Theory and Experiment," in a (ourse and Workshop on Applications of RF Waves to Tokamak Plasmas. larenna, Italy, September. 1985. edited by S. Bernabei, U. Ciasparino and E. Sindoni. produred for the International School of Plasma Phorsics. pages 197 to 235 .

2. M. Ono, P. Beiersdorfer, R. Bell. et al., "Effects of High-Power lon Bernstcin Waves on a Tokamak PJasma," Physical Review Letters, Volume 60. pages $294-296$ (1998). 
Figures

1. Possible Resunances for Ion Bernstein Wate Heating. Resonant fre quency for several hydrogenir ions (protium. denterium, tritium) is plotted against turuidal field in two bands, one ending at $\vec{i}$ Tesla, and one ending at 10 Tesla. The extent of each band toward lower frequency represents the decrease in total field toward the outside major radius. In considering the total fielel. the poloidal field is important at the large major radius edge: therefore. the change in total field is less than the change in turoidal ficld in the range plotted. Heating can be cent ralized with fifth harmonic tritium, and the fuurth harmonic deuterium, and no wher resunances call compete for absorption.

2. Top view of a f-waveguide coupling structure at the plasma. including the coraxial transmission lines which carry power to the experimental rogion. The figure is approximately to scale, as shown.

3. Side view uf the installation shom in Figure 2. The aspect ratio of the wareguide is accurately shown by comparing Figures 2 and 3. 


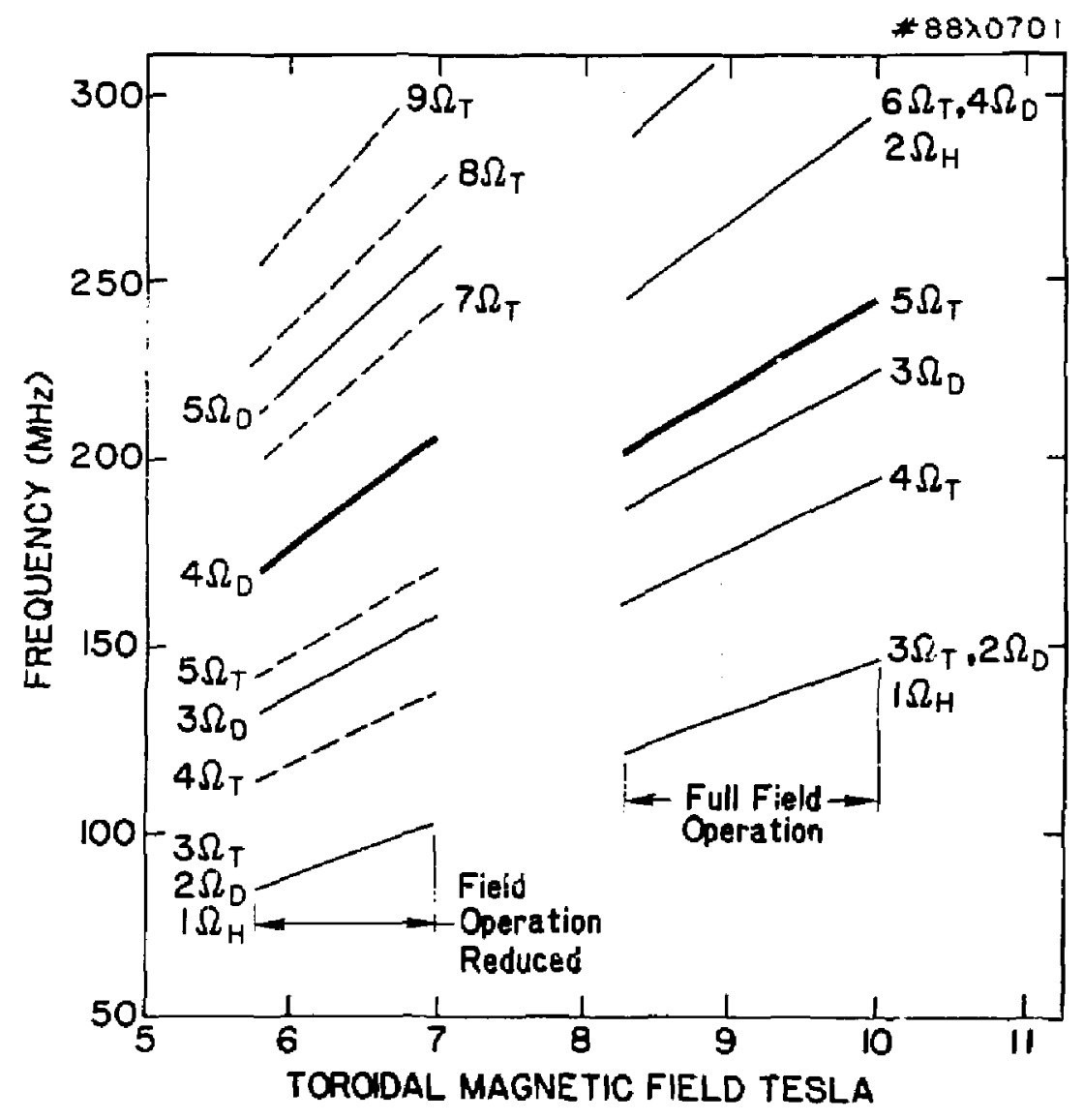

Fig.: 


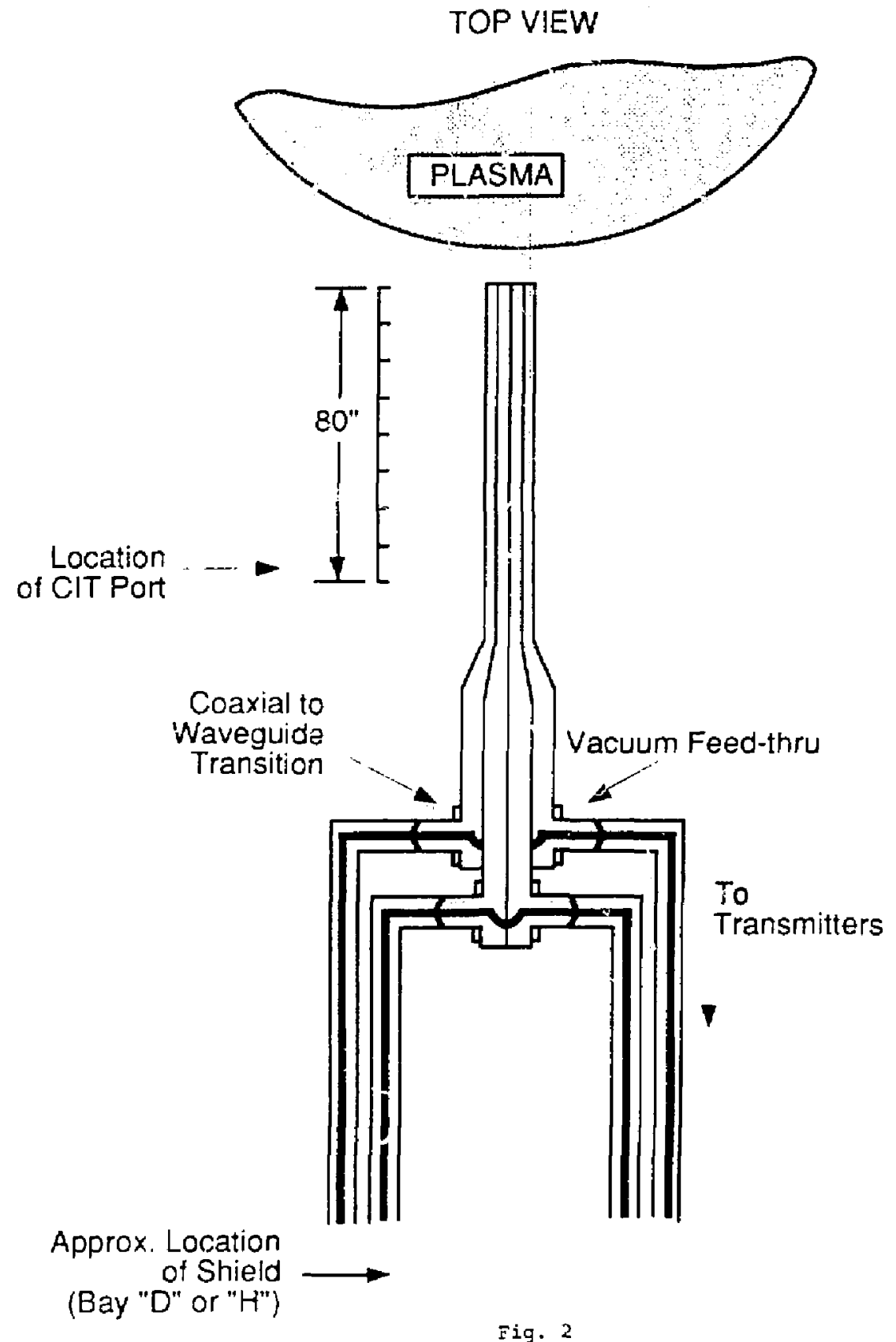

Fig. 2 


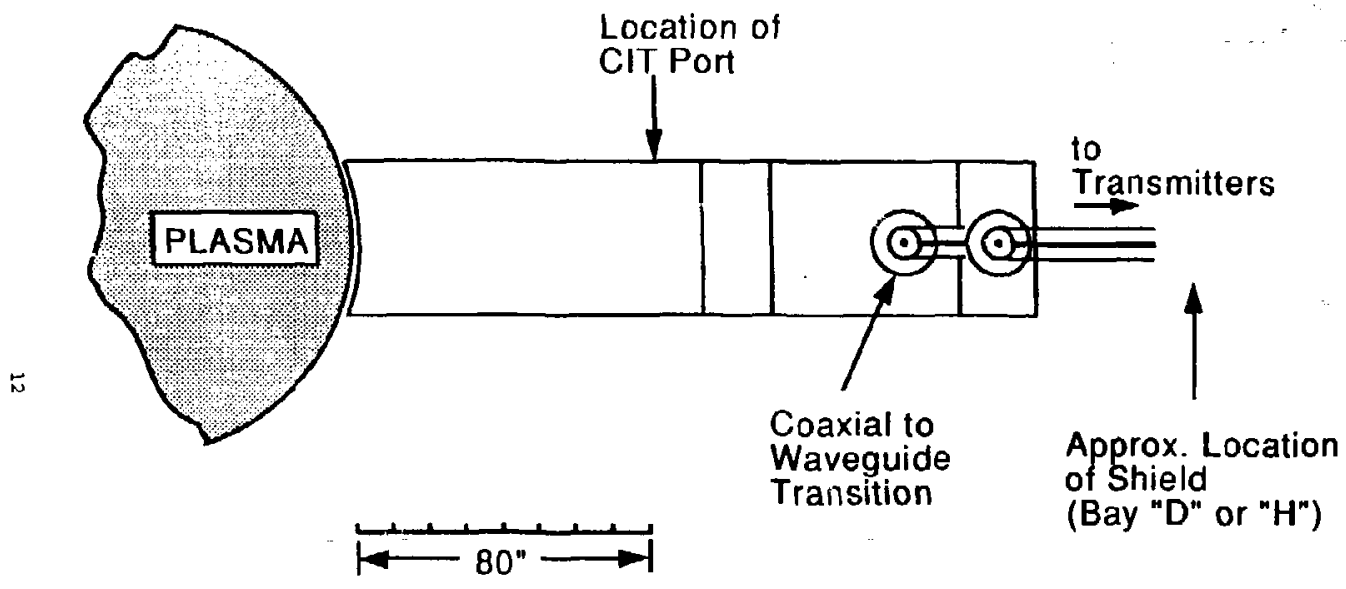

SIDE VIEW 
Dr. Frank J. Paoloni, Univ of wollongong, AUSTRALIA Prol. M.H. Brennan, Univ Syonay, Mustral IA Plasma Rasoarch LaO.. Australian Mat. Univ., AUSTRalia Prof, I.R, Jones, FI inders univ., Australia Prol. F. Cap, Inst theo Phys, Australa

Prol, M, theindler, Institut fur Theoretisene Phys|k, NUSTR1A

M. Goossans, Astronomisch Instituut, BELGILA

Ecole Royale Militaire, La de Phy Plagnas, BELGILM Comission-Eurogean, Dg-X/; fusion Prog, Belglum

Prof. R. Boucique, Laboratoriun voor Mtuurkunde, BeLGILA Dr. P.H. Sakanaka, Instituto Fisica, BRAzIL Instituto Do Pasquisas Espaciasi-IMPE, BRAzIL

Documents Oftice, Atomlc Energy of Canade Limited, CANAM Dr. M.P. Bachynski, wo Technologiex, tace, Caknon Dr. H.M. Skarsgard, University of Sasketcheman, ChwaA Dr, H. Barnard, Univarsity of British Columbia, CANADA Prof, J. To ichmann, Univ. of Montrual, Cavada Prof, S,R. Sreenivasan, University of Colgary, CAMADA Prof. Tuoor W. Johnston, IRPS-Energle, CNubA Dr. C.R. James, Univ. of Alberta, CANADA

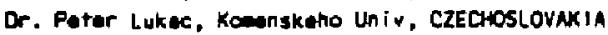
The Librarlan, Culnew Locoratory, EkGLAND The Librarlan. Rutherford ADpleton Laboratory, ENGLNO Mrs. 5.A. riutehingon, JET Library, ENGLAND C. Mouttat, Lab. da Physique das Mll ieux Ion ises, FRArce J. Redet, CEN/CAOARACEE - Bat 506, FRANCE

Uniy. of lounnind, Library of Physics Dept. GeECE Dr. Tan Mul, Acadeay Bibliographic Sor., Howg kans Praprint Library. Hungarian Acadeay of Sciances, Hukary Dr. B. Oasgupta, Saha Inst of Nucl. Phys.. IMola Dr. P. Kaw, Institute for Plasma Resueren, INDIA Dr. Philip Rosendu, Israel Inst. Toch, ISRAEL Librarian, Int'l Ctr Theo Phys, ITALY Prof. G. Rostagni, Univ Di Padova, I TAlY

Miss CIel io De Paio, Assoc EuRATOM-ENEA. ITALY Bibliotece, Instituto di fisica del Plasma, ITALY Dr. H. Yamato, Toshibe Res \& Dav, JAPAN Prof. 1. Kamekami, Atanic Energy Ras. Instituto, JAPAN Prof. Kyoji Nisnikave, Univ of Miroshima, JAPAN

Direc. Dept. Large Tokomak Res. JAER1, JAPAN

Prof. Satoshi Itoh, Kyushu University, JAPRN

Research info Centar, Nogoyd Lnivorsity, JAPAY

Prof, S, Tonaka, Kyoto University, JAPAN

Librery, Kyoto University, JAPAH

Prof. Mobyyuki I noule, University of Jokyo, JAPAM

5. Mor $i$, JAEAI, JAPAN

Librarian, Korea Advancad Energy Res. Institute, KOREA Prof, 0.1. Choi, Adv. Inst Sci \& Tech, KOREA

Prof. B.5. Lilor, University of Waikato. NEW IEALAND Institute of Plasme Physics, PEOPLE's REPLBLIC of CHINA Librarian, Institute of Phys.., PEOPLE'S REPUALIC OF CHINA Library, Tsing Hud University, PEOPLE'S REPUBLIC OF CH:NA
2. Li, Southwast Inst. Physles, Peofle's Repuglic of CHINA Prof. J.A.C. Caboral, Inat Suparior Tecnico, POATugal

Dr. Oetavian Potrus, Al. I CuzA University, ROMANIA Dr. Johen de Villiars, Fusion Studles, AEC, SO AFAICA Prot. M.A. Maliberg, University of Matal, So Affica C.I.E.M.A.T., Fusion Div, Llorary, SPAIN Dr. Lennert Stenflo, Univorsity of LAEA, SWEDEN Library, Roysl Inst Tech, SHEDEN Prot. Hens wilhelmoon, Cholears Univ Teeh, SWEDEN Centre Phrs des Plesmas, Eeale Polytech Fod, SWI T2ERLANO Bibliothaek, Fom-inst Voor Plasan-Fysica, THE NETHERLANOS Dr. D.D. Ryutor, Siberion Aead Sei. USSR

Dr. G.A. El iseer, Kurchator Institute, USSR

Dr. V.A. Glukhikh, Inst Electrophysical Apperatus, USsR Or. Y.T. Tolok, Inst. Phys. Tech. UssR Dr. L.M. Kovrizhnykn, Institute Gen. Physles, USSR Nuelear Ras. Estoblishmont, Julien LTO., W. GERUNT Blbliothek, Inst. Fur plaseseforsenung, W. GERWAY Dr. K. Sehindior, Ruhr Universitat Bochum, W. Gefuhyy ASDEX Rouding Ran. IPPAan+PI anck-Institut t ur

Plasmaphys $k$, w. GeFuny Librarian, Maxtianck Inst i tut, M. GERMAHY Prof. R.K. Janev, Inst Phys, yugoslavia 